\title{
THE MANUFACTURING ISSUES OF TECHNICAL PRODUCTS MADE OF POLYIMIDE - CARBON FIBERS COMPOSITE BY MEANS INJECTION MOULDING PROCESS
}

\begin{abstract}
Nowadays modern commercial simulation software provides acceptably faithful representation of reality, assuming the correctness of boundary conditions and reliability of data of processed composite material. In the case of non-standard plastics which include polyimide, we do not always have access to the target material and we do not have proper equipment to produce such products. Due to very interesting properties of the polyimide and its low popularity in use as an injection moulding material, the analysis of injection moulding of tooth plastic gear made from carbon fiber-polyimide composite was made. In this work the chosen material data, necessary for the numerical analysis, were presented. The impact analysis of main factors controlling the volumetric shrinkage during injection moulding processing was conducted. It was found that the greatest impact on the quality criterion is the melt temperature. To optimize control factors, the Taguchi orthogonal plans were used. In addition, the issue of polyimide properties, the possibility of its injection moulding and applications was discussed.
\end{abstract}

Keywords: polyimides, polymer composites, numerical simulations, optimization, injection moulding

\section{Introduction}

Polyimides are polymers which are created by condensation polymerization of pyromellitic anhydrides and primary diamines. The presence of cyclic groups along the polymer chain (fig. 1) results in good specific properties [9]. These compounds contain group -CO-NR-CO as a part of a ring along the polymer chain, which results in high temperature parameters. Use in the synthesis of pol-

\footnotetext{
${ }^{1}$ Wiesław Frącz, Rzeszow University of Technology, e-mail: wf@prz.edu.pl

2 Autor do korespondencji/corresponding author: Grzegorz Janowski, Rzeszow University of Technology, 8 Powstańców Warszawy Ave., 35-959 Rzeszów, e-mail: gjan@prz.edu.pl

${ }^{3}$ Gennadi Mikhasev, Belarusian State University, e-mail: mikhasev@bsu.by
} 
yimides aromatic diamine provides exceptional thermal stability. As an example, di-(4-amino-phenyl) ether could be used to produce Kapton - polyimide manufactured by DuPoint [6].<smiles>CCn1c(=O)c2cc3c(=O)n(C(C)(C)C)c(=O)c3cc2c1=O</smiles>

Fig. 1. Structure of polyimide

These materials that have very good physical properties are used in terms in which parts are exposed to aggressive environments. They have excellent high temperature properties and oxidative stability which allows them to withstand continuous operation in air at $260^{\circ} \mathrm{C}$ [1]. These materials are combustible, but have affinity for self-extinguishing. They are resistant to weak acids and organic solvents. They also have good electrical properties and are resistant to ionizing radiation. They are further characterized by high tensile strength and modulus, excellent abrasion resistance, resistance to creeping and long-term heat resistance in air or in an inert atmosphere. A disadvantage of polyimide is its ability to hydrolyze. Exposure to water or water vapor above $100^{\circ} \mathrm{C}$ may cause cracking of products made from this polymer [2]. A study where after 1000 hours of exposure in air at $300^{\circ} \mathrm{C}$, these polymers retain $90 \%$ of its tensile strength was conducted. Moreover, after $1500 \mathrm{~h}$ exposure to radiation of the value of about $10 \mathrm{rad}$ and the temperature of $175^{\circ} \mathrm{C}$ form stability was preserved but it became brittle. The first commercial application of polyimide was the use of it as an enamel wire, then as a coating of glass fiber (Pyre ML, Du Pont) and a film (Kapton, Du Pont). Composite laminates produced by impregnating glass fiber and carbon fiber with a polyimide were pressed and cured at a temperature of about $200^{\circ} \mathrm{C}$ and then were cured at temperatures up to $350^{\circ} \mathrm{C}$. Such laminates can be occasionally used continuously at temperatures up to $250^{\circ} \mathrm{C}$ and $400^{\circ} \mathrm{C}$ in the application. The laminates have found use in the aerospace industry, in particular in the production of supersonic aircraft. On the other hand, polyimide foam (Skybond Monsanto) has been used for damping the sound of jet engines. Moreover, fibers from a polyimide by Upjohn and Rhone-Poulenc (KERMEL) were produced $[4,6]$.

Initially, the main problem of above materials was a narrow range of applications due to the fact, that they could not be formed by standard techniques for thermoplastics. In an attempt to overcome this limitation, in the early 1970 s scientists have developed modified polyimides that were more susceptible to processing than common polyimides, but still have significant heat resistance. An 
important compound group of such modified polyimides are polyamide (eg. Torlon synthesized by Amoco Chemicals), polybismaleinimides (eg. Kinel manufactured by Rhone-Poulenc), polyesters imides (e.g. Icdal Ti40 Dynamit Nobel), polyether (e.g., Ultem produced by General Electric). For example Torlon is designed to use ironing pressure and injection moulding. In the case of pressing the pressure-molded compound was heated to $280^{\circ} \mathrm{C}$ then formed at the $340^{\circ} \mathrm{C}$ at a pressure of $30 \mathrm{MPa}$. Next to $260^{\circ} \mathrm{C}$ before the end of the process it was cooled. For injection moulding, plasticized Torlon was injected at about $355^{\circ} \mathrm{C}$ into a mold maintained at a temperature of $230^{\circ} \mathrm{C}$. Products from this material are used to produce: pumps, valves, refrigeration components and electronic components. Typical properties of unfilled polyimide were compared in table $1[4,10,17]$.

Table 1. Some mechanical and thermal properties of unfilled polyimides

\begin{tabular}{|c|c|c|c|c|c|}
\hline Attribute & Temperature & $\begin{array}{c}\text { Kinel } \\
\text { (Rhone- } \\
\text { Poulenc) }\end{array}$ & $\begin{array}{c}\text { Ultem } \\
\text { (General } \\
\text { Electric) }\end{array}$ & $\begin{array}{l}\text { Vespel } \\
\text { (ICI) }\end{array}$ & $\begin{array}{l}\text { Torlon } \\
\text { (Amoco) }\end{array}$ \\
\hline \multirow{3}{*}{$\begin{array}{c}\text { Flexular modulus } \\
{[\mathrm{GPa}]}\end{array}$} & $25^{\circ} \mathrm{C}$ & 3.8 & 3.3 & 3.5 & 4.6 \\
\hline & $150^{\circ} \mathrm{C}$ & - & 2.5 & 2.7 & 3.6 \\
\hline & $260^{\circ} \mathrm{C}$ & 2.8 & - & 2.3 & 3.0 \\
\hline $\begin{array}{l}\text { Heat distortion tem- } \\
\text { perature }\left[{ }^{\circ} \mathrm{C}\right]\end{array}$ & & - & 200 & 357 & 282 \\
\hline \multirow{3}{*}{$\begin{array}{c}\text { Tensile strength } \\
{[\mathrm{MPa}]}\end{array}$} & $25^{\circ} \mathrm{C}$ & $\sim 40$ & 100 & 90 & 186 \\
\hline & $150^{\circ} \mathrm{C}$ & - & - & 67 & 105 \\
\hline & $260^{\circ} \mathrm{C}$ & $\sim 25$ & - & 58 & 52 \\
\hline
\end{tabular}

\section{Thermoplastic polyimide with carbon fiber}

Polyimide - carbon fiber composites, for example Aurum JCL 3030, is a material designed for injection moulding process. This composite has high mechanical (Tab. 2) and thermal properties (Tab. 3), which allows to use it in many industries such as automotive, machine, aerospace, electronics. This material has good dimensional stability, radiation resistance, resistance to fluids and industrial solvents, low thermal expansion coefficient, creep resistance and low flammability, low wear rate, low surface friction over a wide range of temperatures in dry and lubricating conditions.

Table 2. Mechanical properties of polyimide carbon fiber composite - AURUM JCL 3030 [13]

\begin{tabular}{|c|c|c|c|c|c|}
\hline Attribute & $\begin{array}{c}\text { Tensile } \\
\text { strength } \\
{[\mathrm{MPa}]}\end{array}$ & $\begin{array}{c}\text { Elongation } \\
{[\%]}\end{array}$ & $\begin{array}{c}\text { Flexural } \\
\text { strength } \\
{[\mathrm{MPa}]}\end{array}$ & $\begin{array}{c}\text { Modulus of } \\
\text { elasticity } \\
{[\mathrm{MPa}]}\end{array}$ & $\begin{array}{c}\text { Compressive } \\
\text { strength [MPa] }\end{array}$ \\
\hline $22.98^{\circ} \mathrm{C}$ & 229 & 2 & 314 & 17.2 & 207 \\
\hline $148.89^{\circ} \mathrm{C}$ & 144 & 4 & 216 & 15.2 & 102 \\
\hline $\begin{array}{c}\text { Measurement } \\
\text { method }\end{array}$ & \multicolumn{2}{|c|}{ ASTM D-638 } & \multicolumn{2}{c|}{ ASTM D-790 } & JIS K-7208 \\
\hline
\end{tabular}


AURUM JCL 3030 can be processed by means of injection moulding technology at melt temperature above $400^{\circ} \mathrm{C}$ and mold temperature of $200^{\circ} \mathrm{C}$. The granulate should be dried prior to the processing in the oven with air circulation under the following conditions: 8 hours at $220^{\circ} \mathrm{C}, 10$ hours at a temperature of $200^{\circ} \mathrm{C}$ and 12 hours at a temperature of $356^{\circ} \mathrm{C}$. The injection pressure should be in a range between $75.84 \mathrm{MPa}-241.32 \mathrm{MPa}$, screw speed of 100-200 rpm. AURUM can be cleaned through unfilled or glass fiber reinforced polyether, polysulfone and polyetherimide.

Table 3. Thermal properties of polyimide carbon fiber composite - AURUM JCL 3030 [14]

\begin{tabular}{|c|c|c|}
\hline Attribute & Measurement method & Value \\
\hline Melting temperature $\left[{ }^{\circ} \mathrm{C}\right]$ & DSC & 388 \\
\hline Glass transition temperature $\left[{ }^{\circ} \mathrm{C}\right]$ & DSC & 250 \\
\hline Melt Index $[\mathrm{g} / 10$ min] & ASTM D-1238 & $27-37$ \\
\hline $\begin{array}{c}\text { Coefficient of thermal expansion }\left[10^{-}\right. \\
\left.5 /{ }^{\circ} \mathrm{C}\right]\end{array}$ & ASTM D-696 & $(0.6 \mathrm{MD} / 4.7 \mathrm{TD})$ \\
\hline Heat deflection temperature $\left[{ }^{\circ} \mathrm{C}\right]$ & ASTM D-648 & 248 \\
\hline
\end{tabular}

The components produced from composite polyimide-carbon fiber are excellent substitutes for metals, ceramics, and other plastics. Products with high strength may be manufactured in form of: thrust washers and o-rings oil for automotive gear and off road vehicles, thermal insulators, parts of jet engines, check ball valves, fittings spline, heat-resistant gears, blades, wear strips and valve seats. Other applications include: elements for hard drives and aluminum silicon wafers, plain bearings and handles [7, 13, 14, 17].

\section{The simulation of injection moulding process}

Plastic gear wheels are products in which technological problems still occur. Due to the considerable thickness of the walls and their frequent variation, it is difficult to get the proper dimensional accuracy $[3,12]$. The main factor which determining for obtaining a correct dimension is shrinkage of the part. Keeping of this value in the required range depends on many factors such as: mold temperature, melt temperature, injection time. Substitution of any of these parameters results in a change in the shrinkage processing, thus changing the geometric dimensions of the part. To determine the required parameters of the injection molding process a lot of experimental tests should be made. In the case of nonstandard plastic we do not always have access to target material and we do not have proper equipment to form such product. These restrictions may be replaced by numerical simulations. Numerical analysis can give interesting results, data and often give a solid foundation to start experimental research. There are many economic and technical aspects, which incline to use software, such as CAE. The technical factors include: possibility of process accuracy increasing, antici- 
pated problems and their solutions at design stage, the choice of suitable raw materials and optimize process parameters. It is also worth mentioning economic aspects, which include a material saving, while reducing a number of prototype versions and preparation time [5].

Due to the very interesting properties of the polyimide and its low popularity in use as an injection molding material, numerical analysis of gear injection molding process of polyimide-carbon fiber composite was made. The steps of simulation included: the geometrical model preparing, model discretization using 3D finite elements (FE) of tetra type, setting of initial and boundary conditions, numerical analysis and simulation results interpretation. The geometrical model of the gear was designed in the NX8 (fig.2a). Computer simulations were performed using Autodesk Moldflow Insight 2013. The analyzed material with the trade name AURUM JCL3030 - polyimide filled with 30\% carbon fiber was used. The numerical model of the gear consisted of over $320000 \mathrm{FE}$ (fig. 2b).

a)

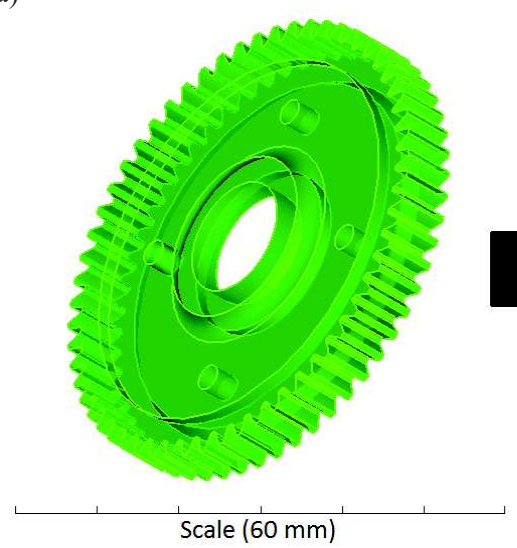

b)

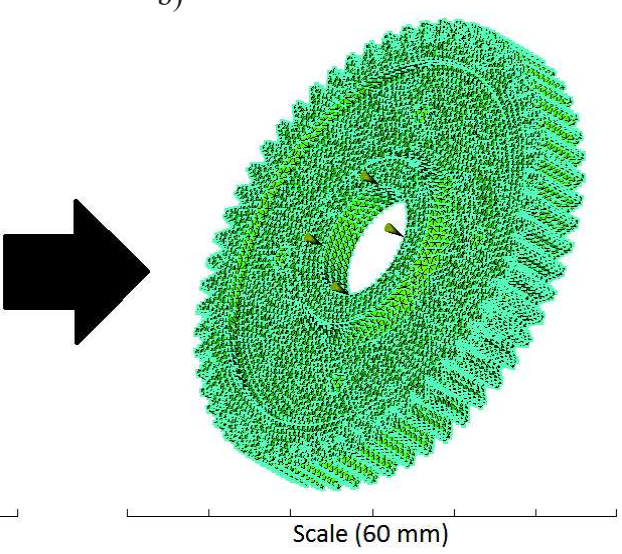

Fig. 2. Gear models: a) geometric model, b) discretized 3D mesh model with injection points locations

\section{PVT and rheological characteristics of polyimide-carbon fi- ber composites}

One of the major stages of the simulation test is to define the data describing properties of the processed materials. In the case of polymer composite these data include thermal, rheological, optical, mechanical and processing properties for both polymer matrix and fiber filler.

To carry out the simulation it is necessary to adopt rheological equation of polymer state, which defines the relationship between the viscosity of the polymer, and shear rate. Among the well-known mathematical models the 7parameter rheological Cross-WLF model was used, which provides a relatively accurate mathematical description of rheological properties of the polymer. In 
this model the viscosity of the polymer is determined by Cross equation $[11,15$, 16]:

$$
\eta(\dot{\gamma}, T, p)=\frac{\eta_{0}(T, p)}{1+\left(\frac{\eta_{0} \cdot \dot{\gamma}}{\tau^{*}}\right)^{1-n}}
$$

where: $\eta$ - viscosity of melt polymer, $T$ - temperature, $p$ - pressure, $n$ and $\tau^{*}$ - constant parameters of the model, $\eta_{o}$ - the zero shear viscosity. The zero shear viscosity is calculated from the equations by Williams-LandelFerry (WLF):

$$
\eta_{0}(T, p)=D_{1} \cdot \exp \left[-\frac{A_{1} \cdot\left(T-T^{*}\right)}{A_{2}+\left(T-T^{*}\right)}\right]
$$

wherein:

$$
T^{*}(p)=D_{2}+D_{3}
$$

and

$$
A_{2}+A_{3}+D_{3} p
$$

where: $T^{*}$ - glass transition temperature, D1, D2, D3, $A_{1}, A_{2}, A_{3}$ - constant parameters of the WLF model.

The parameters of the Cross-WLF model were found in the material database of Autodesk Moldflow Insight 2013 commercial code (tab. 4). Figure 3 shows the viscosity curve used in the numerical analysis.

Table 4. The values of model parameters Cross-WLF for composite AURUM JCL3030

\begin{tabular}{|c|c|c|c|c|c|c|c|}
\hline Parameter & $\mathrm{n}$ & $\tau^{*}$ & $\mathrm{D} 1$ & $\mathrm{D} 2$ & $\mathrm{D} 3$ & $\mathrm{~A} 1$ & $\mathrm{~A} 2 \sim$ \\
\hline Unit & - & {$[\mathrm{Pa}]$} & {$[\mathrm{Pa} * \mathrm{~s}]$} & {$[\mathrm{K}]$} & {$[\mathrm{K} / \mathrm{Pa}]$} & - & {$[\mathrm{K}]$} \\
\hline Value & 0.4809 & 15880 & $1.271 \mathrm{e} 013$ & 523.14 & 0 & 25.17 & 51.6 \\
\hline
\end{tabular}




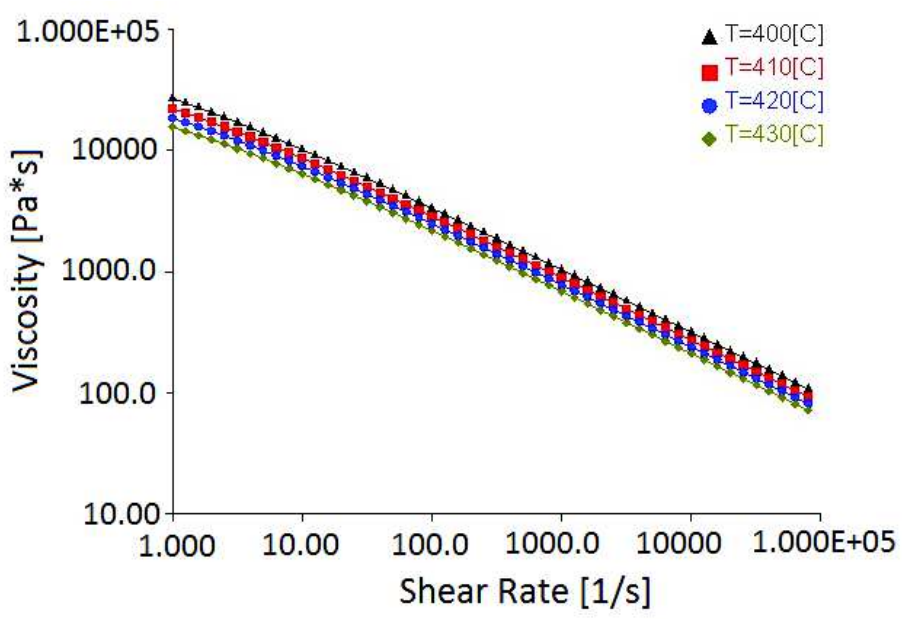

Fig. 3. Viscosity vs. shear rate graph for AURUM JCL3030composite

To determine the composite volumetric shrinkage it is necessary to know the $\mathrm{p}-\mathrm{V}-\mathrm{T}$ characteristics. In numerical calculations the Tait equation was used, which shows the specific volume change as a function of temperature and pres-

sure. The Tait model is given by equations $[8,9,15]$ :

$$
v(T, p)=v_{0}(T)\left[1-C \ln \left(1+\frac{p}{B(T)}\right)\right]+v_{t}(T, p)
$$

where: $v_{t}(T, p)$ - specific volume at a given temperature and pressure, $T$ - temperature, $p$ - pressure, $C$ - constant $(C=0.0894), B$ - pressure sensitivity of the material, defined below:

when $\left.T>T_{t}\right)$ :

$$
\begin{aligned}
& v_{0}=b_{1 m}+b_{2 m}\left(T-b_{5}\right) \\
& B(T)=b_{3 m} \exp \left[-b_{4 m}\left(T-b_{5}\right)\right] \\
& v_{t}(T, p)=0
\end{aligned}
$$

where: $b_{1 m}, b_{2 m}, b_{3 m}, b_{4 m}, b_{5}$ - data-fitted coefficients (describes the volumetric transition temperature, at zero gauge pressure) when $T<T_{t}$ :

$$
v_{0}=b_{1 S}+b_{2 S}\left(T-b_{5}\right)
$$




$$
\begin{aligned}
& B(T)=b_{3 S} \exp \left[-b_{4 S}\left(T-b_{5}\right)\right] \\
& \left.v_{t}(T, p)=b_{7} \exp \left[b_{8}\left(T-b_{5}\right)\right)-\left(b_{9} p\right)\right]
\end{aligned}
$$

$b_{1 S}, b_{2 S}, b_{3 S}, b_{4 S}, b_{5}, b_{6}, b_{7}, b_{8}, b_{9}$ - data-fitted coefficients.

Figure 4 shows the relationship between specific volume and temperature under different pressures. Viscosity curves and $\mathrm{p}-\mathrm{v}-\mathrm{T}$ graph were assumed by Autodesk Moldflow material database, based on experimental data.

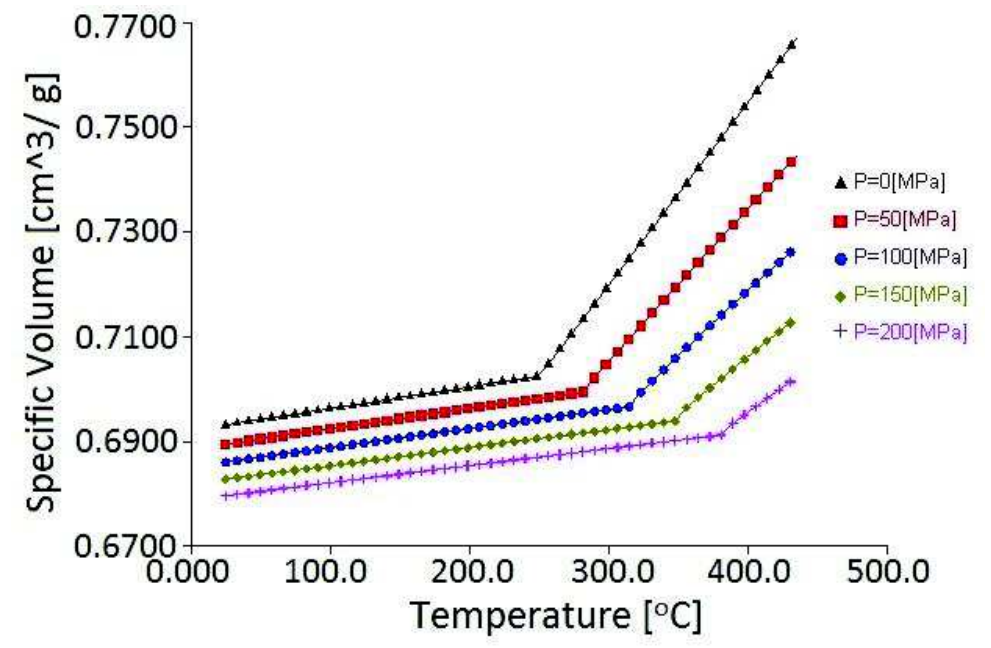

Fig. 4. The p-v-T graph for AURUM JCL3030 composite

\section{The optimization of injection moulding parameters}

The processing parameters have been optimized using Taguchi method. In the analysis the control factors were following: the melt temperature in the range of $400^{\circ} \mathrm{C}$ to $440^{\circ} \mathrm{C}$, mold temperature in the range of $180^{\circ} \mathrm{C}$ to $220^{\circ} \mathrm{C}$, injection time in the scope of $0.8 \mathrm{~s}$ to $1.2 \mathrm{~s}$, holding time in the range $10-14 \mathrm{~s}$ and holding pressure in the scope of $70 \%-90 \%$ of the injection pressure. Scopes of input parameters were based on the literature and material database of Autodesk Moldflow Insight 2013 commercial code.

As quality criteria, the volumetric shrinkage at ejection was selected. The optimization analysis was made through the design of the experiment, implemented in the program. Based on calculations, the impact of the main factors controlling the value of shrinkage was estimated. It was found that the melt temperature has the greatest impact on the quality criterion (fig. 5). Several important computer calculations have been conducted, which allowed to obtain optimal injection parameters: the melt temperature $-400^{\circ} \mathrm{C}$, mold temperature - 
$220^{\circ} \mathrm{C}$, injection time $0.8 \mathrm{~s}$, holding pressure of $90 \%$ of the injection pressure and holding time $12 \mathrm{~s}$. The lowest shrinkage value was received using these parameters. The range of optimum processing parameters vs. control parameters were illustrated by means of response surface method RSM (figs. 6-8).

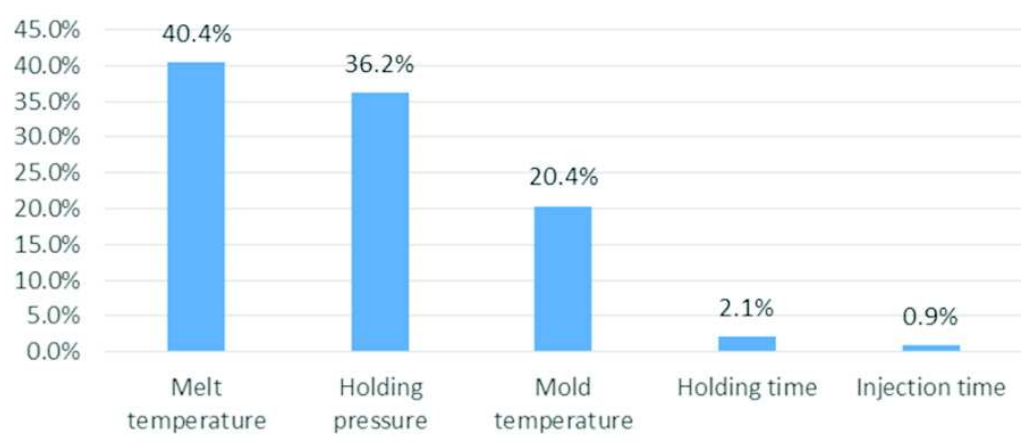

Fig. 5. Percentage impact of the main factors controlling the value of shrinkage at ejection

The analysis of numerical simulation results were focused on the basic process parameters, i.e. filling certainty of the mold cavity, fiber orientation and weld lines. Analyzing the composite flow it was found that the mold cavity was filled efficiently. Weld lines in the plastic gear molded piece are formed predominantly due to connection of the jet forming stream according to the complex structure of the part. In these places the decreasing of composite strength takes place. Weld lines created in the gear molded piece are shown in figure 9a. The most likely occurrence places of weld lines are in the vicinity of assembly holes.

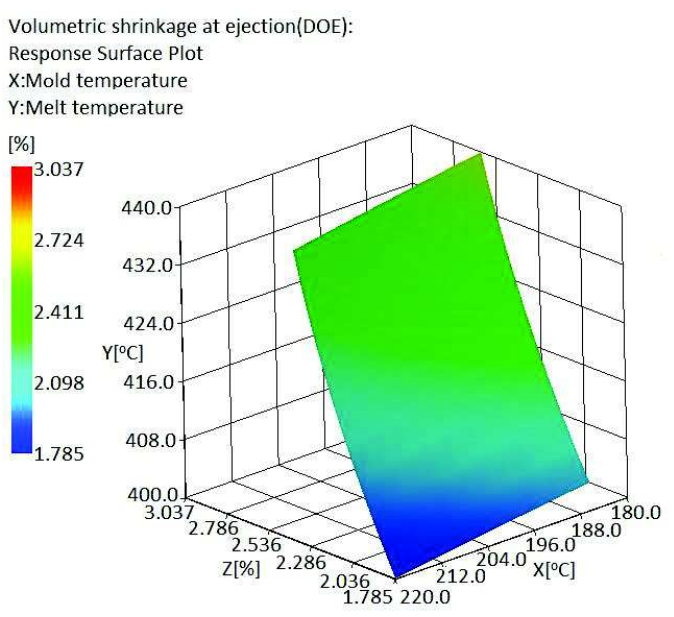

Fig. 6. RSM surface plots of volumetric shrinkage for factors: mold temperature and melt temperature 


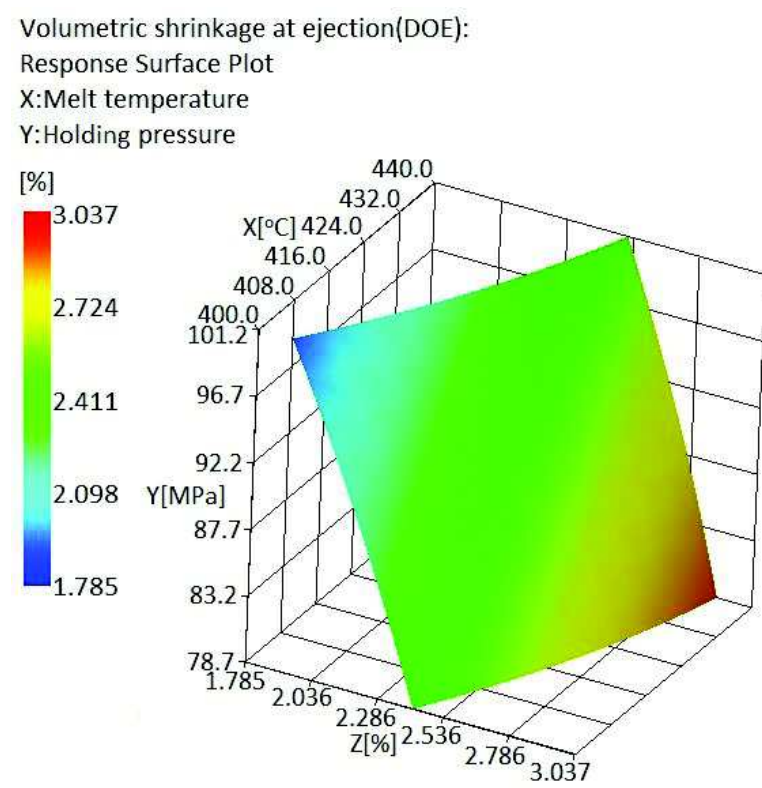

Fig. 7. RSM surface plots of volumetric shrinkage for factors: melt temperature and holding pressure

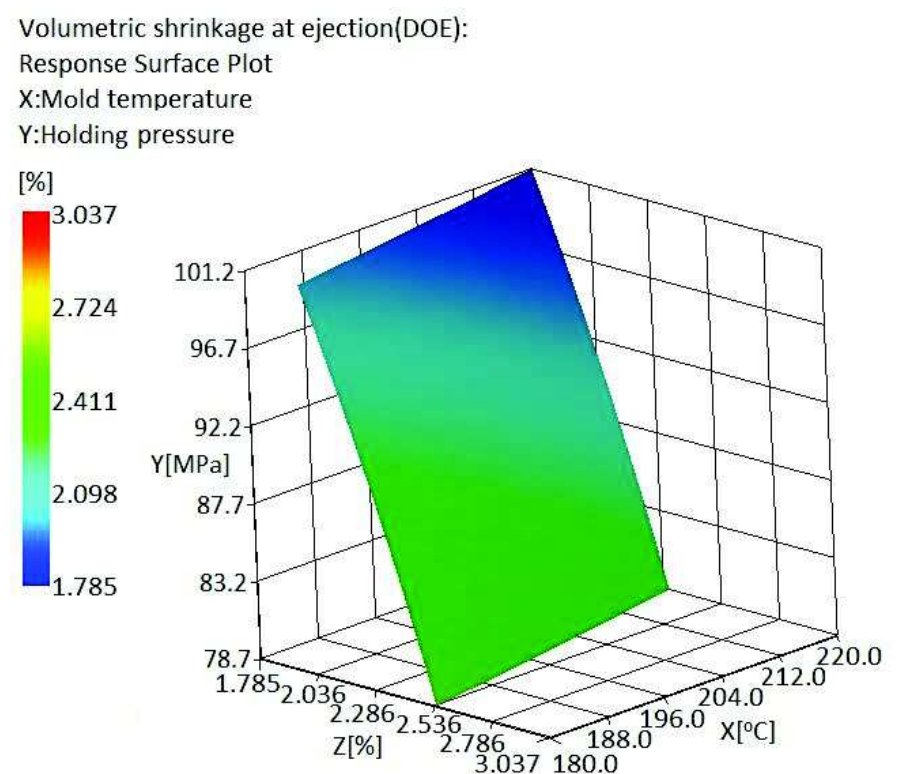

Fig. 8. RSM surface plots of volumetric shrinkage for factors: mold temperature and holding pressure 
a)

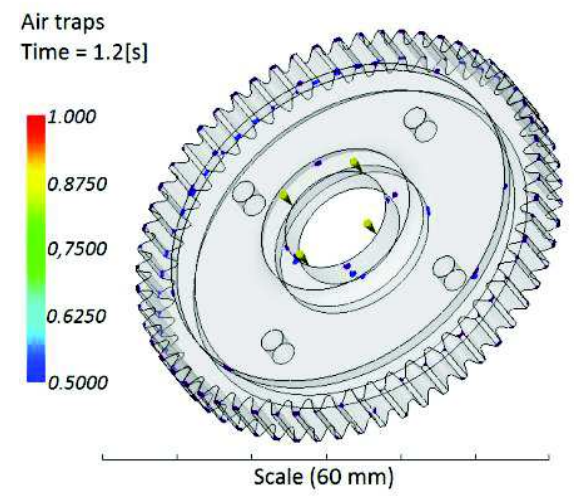

b)

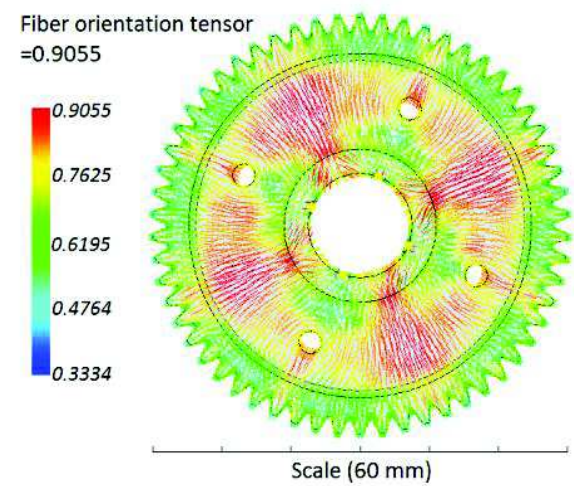

Fig. 9. Presentation: a) line connecting the composite, b) fiber orientation tensor

In the calculations of fiber orientation the Tucker - Folgar model was applied. It was used a numerical procedure that allows to calculate the coefficient of the interaction of the fibers and the polymer matrix. Elastic properties of composites reinforced with short fibers were calculated on the base of micromechanical Halpin-Tsai model. Elastic properties of the polymer matrix and fiber content and their shape factor were included. The unidirectional composite reinforcement was assumed. To determine the coefficients of thermal expansion: for both longitudinal and transverse direction, the Rosen-Hashine model was selected. Disorders of fibers orientation were undoubtedly associated with the change of molded piece geometry and polymer flow path (fig. 9b).

\section{Conclusions}

The results of the analysis of numerical simulations indicate that the specialized computer programs allow to predict phenomena in specific technological processes. Modern simulation commercial codes provide acceptably faithful representation of reality, assuming the correctness of initial and boundary conditions and the reliability of material data. In the case of non-standard plastic, as in the case of polyimide, we do not always have access to the target material and we do not have proper equipment to enable the manufacturing of such product. Due to the very interesting properties of the polyimide and its low popularity in use as an injection molding material, an analysis of injection molding process of the gear made from this composite was made. In this work the chosen material data necessary for numerical analysis were presented. The impact analysis of the main factors controlling the value on volumetric shrinkage during the injection mouldings was conducted. It was found that the greatest impact on the quality criterion was the melt temperature. Injection parameters were optimized using orthogonal Taguchi plans. It was also found that the processing parameters of 
the polyimide determine to use of non-standard machines and equipment for processing by injection moulding technology.

\section{Acknowledgement}

The research leading to these results has received funding from the People Programme (Marie Curie International Research Staff Exchange) of the European Union's Seventh Framework Programme FP7/2007-2013/ under REA grant agreement $n^{\circ}$ PIRSES-GA2013-610547.

\section{References}

[1] Berins M.L.: Plastics Engineering Handbook of the Society of the Plastics Industry, 5th ed., Chapman and Hall, New York 1991.

[2] Brydson J.A.: Plastics Materials, 6th ed., Butterworth-Heinemann, Oxford 1995.

[3] Budzik G., Bernaczek J., Kozik B., Sobolewski B., Sobolak M., Oleksy M., Grzelka M., Dobrowolska A.: Advanced integrated cad/rp systems in manufacturing process of planetary gear demonstrator, Acta Technica Corviniensis-Bulletin of Engineering, 6 (2013) 95.

[4] Chanda M., Roy S. K.: Plastics Technology Handbook, CRC Press, Boca Raton 2007.

[5] Gajdoš I., Duleba B., Spišák E., Greškovič F., Dulebová L.: Optimization of injection molding process by DOE, Hutnik - Wiadomosci Hutnicze, 81 (2014) 470- 475.

[6] Harper C.A.: Handbook of Plastics Technologies: The Complete Guide to Properties and Performance, McGraw-Hill, New York 2006.

[7] Harper C. A., Petrie, E. M.: Plastics Materials and Processes: A Concise Encyclopedia, Wiley, Berlin 2003.

[8] Kowalska B., Sikora R.: The effect of cooling time of the injection moldings on the therodynamic equation of state, Polimery, 48 (2003) 359-364.

[9] Kroschwitz, J.I.: Concise Encyclopedia of Polymer Science and Engineering, John Wiley and Sons, New York 1990.

[10] Kutz M.: Applied Plastics Engineering Handbook, William Andrew, 2011.

[11] Kwiatkowski D., Gnatowski A., \& Nabiałek J.: Numerical analysis of residual stress and deformation of injection moulded parts manufactured from polymeric composite with different processing conditions. Kompozyty, 11 (2011) 294-298.

[12] Marciniec A., Budzik G., Sobolewski B., Grzelka M., Wieczorkowski M.: Ocena dokładności prototypów stożkowych kół zębatych z zastosowaniem CMM, Czasopismo Techniczne. Mechanika, 107 (2010) 73-80.

[13] AURUM® JCL3030 Thermoplastic Polyimide - Product data.

[14] AURUM ${ }^{\circledR}$ JCL3030 Thermoplastic Polyimide - Product data.

[15] Pötsch G., Michaeli W., Injection Molding. An Introduction, Carl Hanser Verlag, Munich 2008.

[16] Wilczyński K., Reologia w przetwórstwie tworzyw sztucznych, WNT, Warszawa 2001. 
[17] Yang H., Liu J., Ji M., Yang S.: Novel thermoplastic polyimide composite materials, INTECH open science 2012, pp. 1-11.

\section{PROBLEMATYKA WYTWARZANIA WYROBÓW TECHNICZNYCH Z KOMPOZYTÓW TYPU POLIIMID - WLÓKNO WEGLOWE W TECHNOLOGII FORMOWANIA WTRYSKOWEGO}

\section{Streszczenie}

Współczesne programy symulacyjne w dość wierny sposób zapewniają odzwierciedlenie rzeczywistych procesów wytwarzania, przy założeniu poprawnie wprowadzonych warunków przeprowadzania procesu oraz danych przetwarzanego materiału. W przypadku nietypowych tworzyw sztucznych jakim jest m.in. poliimid - nie zawsze mamy dostęp do materiału oraz odpowiedniej aparatury w celu przetworzenia takiego wytworu. $Z$ uwagi na bardzo interesujące właściwości poliimidu i małą popularność jako materiału nadającego się do wtryskiwania, wykonano symulację formowania wtryskowego koła zębatego wykonanego z kompozytu poliimid - włókno węglowe. W pracy zestawiono dane materiałowe niezbędne do przeprowadzenia analizy numerycznej. Dokonano analizy wpływu głównych czynników sterujących na wartość skurczu objętościowego wypraski. Stwierdzono, że największy wpływ na w/w kryterium jakościowe ma temperatura uplastycznionego tworzywa. Dokonano optymalizacji parametrów wtrysku z wykorzystaniem planów ortogonalnych Taguchi, w oparciu o które przeprowadzono analizy numeryczne. Ponadto, w oparciu o dostępną literaturę przedstawiono istotne właściwości poliimidu, jego aktualne możliwości przetwórstwa oraz obszary jego zastosowania jako materiału konstrukcyjnego.

Słowa kluczowe: poliimidy, kompozyty polimerowe, symulacje numeryczne, optymalizacja, formowanie wtryskowe

DOI: $10.7862 / \mathrm{rm} .2016 .9$

Otrzymano/received: $28.04 .2016 r$

Zaakceptowano/accepted: 16.05.2016r. 